\title{
Nomenclatural and taxonomic comments on some taxa of Dysphania (Chenopodiaceae s. str. / Amaranthaceae s. l.)
}

\author{
Sergei L. MOSYAKIN* \\ M.G. Kholodny Institute of Botany, National Academy of Sciences of Ukraine, Tereschenkivska Str. 2, Kyiv 01601, Ukraine
}

\begin{abstract}
Following the comprehensive molecular phylogenetic results presented by Uotila et al. (2021), comments are provided on the infrageneric classification system of the genus Dysphania in its amended circumscription. Amendments and additions to the five-section scheme of Uotila et al. (2021) are proposed. In particular, the morphologically distinct lineage containing Dysphania atriplicifolia (earlier widely recognized in the monospecific genus Cycloloma as C. atriplicifolium) is recognized as a separate section, Dysphania sect. Cycloloma (Moq.) Mosyakin, comb. et stat. nov. Extensive synonymy of the section and its species is provided. The subclades revealed in the Australian clade of Dysphania sect. Dysphania are rather well characterized morphologically and were treated earlier as sections of either Chenopodium (sensu lato) or Dysphania. These subclades are recognized here as three subsections of sect. Dysphania: (1) subsect. Orthospora (R.Br.) Mosyakin, comb. et stat. nov.; (2) subsect. Dysphania; and (3) subsect. Tetrasepalae (Aellen) Mosyakin, comb. et stat. nov. The nomenclature of Dysphania graveolens (三 Chenopodium graveolens) is discussed. It is confirmed that the name Chenopodium graveolens was first validated not by Willdenow in 1809 but by Lagasca and Rodríguez in 1802. Original specimens associated with that name in both publications belong taxonomically to the same species currently known as D. graveolens (= Chenopodium incisum Poir.). In my opinion, Art. 41.8(a) of the ICN (Shenzhen Code) is directly applicable here. Consequently, the name D. graveolens should be cited with the corrected authorship "(Lag. \& Rodr.) Mosyakin \& Clemants", and the new combination in Dysphania based on Chenopodium incisum (provisionally cited in POWO as "Dysphania incisa (Poir.) ined.") is unnecessary.
\end{abstract}

Keywords: Chenopodium, Cycloloma, Dysphania, nomenclature, taxonomy

Article history. Submitted 17 July 2021. Revised 11 August 2021. Published 30 August 2021

Citation. Mosyakin S.L. 2021. Nomenclatural and taxonomic comments on some representatives of Dysphania (Chenopodiaceae s. str. / Amaranthaceae s. 1.). Ukrainian Botanical Journal, 78(4): 266-273. https://doi.org/10.15407/ ukrbotj78.04.266

*Corresponding author (e-mail: s_mosyakin@hotmail.com)

\section{Introduction}

Since the initial re-circumscription of Dysphania R.Br. (Chenopodiaceae s. str. / Amaranthaceae s. 1.; see Hernández-Ledesma et al., 2015; Morales-Briones et al., 2021) to include glandular-pubescent taxa earlier placed in Chenopodium L. sensu lato (see e.g., Mosyakin, Clemants, 2002, 2008; Clemants, Mosyakin, 2003 , etc.), several new and/or resurrected taxa have been added to the genus and further adjustments of the circumscription of Dysphania have been proposed (see Fuentes-Bazan et al., 2012a, b; Uotila, 2013; Uotila et al., 2021, and references therein). In particular, Teloxys aristata (L.) Moq. has been proved to be a member of the phylogenetically distinct genus Teloxys Moq. (MoquinTandon, 1834: 289), whereas Cycloloma Moq. (MoquinTandon, 1840: 17), the monospecific genus that contained C. atriplicifolium (Spreng.) J.M.Coult. (Coulter in Britton et al., 1894: 143), was revealed as phylogenetically nested in Dysphania near the clade corresponding to Dysphania sect. Adenois (Moq.) Mosyakin \& Clemants (2002: 382; see also Simón, 1996, 1997). In contrast, Australasian Rhagodia R.Br. and Einadia Raf. (Scott, 1978a; Wilson, 1983, 1984) were revealed as members

(C) 2021 S.L. Mosyakin. Published by the M.G. Kholodny Institute of Botany, NAS of Ukraine. This is an open access article under the terms of the Creative Commons Attribution License (http://creativecommons.org/licenses/by/4.0/), which permits use, distribution, and reproduction in any medium, provided the original work is properly cited 
of a re-circumscribed Chenopodium (see FuentesBazan et al., 2012a, b; Mosyakin, Iamonico, 2017, and references therein). In general, the infrageneric taxonomy of Dysphania is now rather well understood, but several morphologically deviant and geographically restricted taxa, in particular, D. stellata (S.Watson) Mosyakin \& Clemants from Mexico, the Central American taxon D. dissecta (Moq.) Mosyakin \& Clemants, and the South American D. minuata (Aellen) Mosyakin \& Clemants, currently remain unplaced to sections or clades (see Mosyakin, Clemants, 2008: 429; Uotila et al., 2021).

In the present article I provide additional comments on and adjustments to the infrageneric system of Dysphania, following the recent treatment of the genus by Uotila et al. (2021) and taking into consideration the earlier infrageneric classifications and taxonomic treatments (Aellen, 1930a, b; Scott, 1978b; Wilson, 1983, 1984; Mosyakin, Clemants, 2002, 2008, etc.), and also consider the nomenclatural case of Chenopodium graveolens, which affects the nomenclature of the species that was until recently accepted as Dysphania graveolens, with the authorship usually cited as "(Willd.) Mosyakin \& Clemants".

\section{On Cycloloma and its infrageneric placement in a re-circumscribed Dysphania}

The nomenclature and taxonomy of a morphologically very peculiar species until recently known mainly under the name Cycloloma atriplicifolium (Spreng.) J.M.Coult. (see Coulter in Britton et al., 1894; Standley, 1916; Mosyakin, 2003, and references therein) was haunted by many problems. When Moquin-Tandon decided to segregate that North American species in a genus of its own, he first considered the generic name Amoreuxia Moq. (a later homonym of Amoreuxia DC., now placed in Bixaceae, formerly Cochlospermaceae) and then, in 1834, described in detail the genus Cyclolepis Moq. (not mentioning the name Amoreuxia), but that name again turned to be a later homonym, this time of Cyclolepis Gillies ex D.Don (Asteraceae). Finally, the name Cycloloma Moq. was proposed in 1840 as the replacement name for the illegitimate generic name Cyclolepis Moq. (see Moquin-Tandon, 1834, 1840, 1849). Reichenbach $(1841: 153,236)$ also noticed the homonymy of Cyclolepis and proposed the replacement name Petermannia Rchb., but that name was published later than Cycloloma. The generic name Amorea was attributed by Delile (1844: 1) to Moquin-Tandon; however, Moquin-Tandon (1849) did not recognize his authorship of that name and instead attributed it to Delile only. Delile (1844) did not provide any description of the genus Amorea but his citation of "Amorea platyphylla Moquin" can be interpreted as indirect reference (Art. 38.14 and 41.3 of the ICN: Turland et al., 2018) to the name Cyclolepis platyphylla (Michx.) Moq. and MoquinTandon's description of Cyclolepis.

The only species of Cycloloma was placed by earlier authors in Salsola L. (Sprengel, 1801, etc.), Kochia Roth, or Chenopodium (see the nomenclatural citations below), in addition to the generic names mentioned above, and in synonymy below. Its placement in Salsola sensu lato or Kochia sensu lato was, undoubtedly, due to the presence of a transverse horizontal wing encircling the perianth. That wing is, however, only superficially similar to winglike appendages present on perianth segments in many taxa of Salsoloideae and Camphorosmoideae (see Kühn et al., 1993; Cabrera et al., 2009, 2011; Kadereit, Freitag, 2011, etc.) and its development is different. Because of that the placement of Cycloloma in Camphorosmeae (Scott, 1978c; Kühn et al., 1993) was not justified and, as I noted earlier (Mosyakin, 2003: 265), "Cycloloma is more closely related to Chenopodium in the broad sense; the problem of its proper placement requires additional study".

Recent molecular phylogenetic results (Uotila et al., 2021) demonstrated that Cycloloma is nested within the re-circumscribed genus Dysphania and is most probably sister to the large clade of American taxa recognized as Dysphania sect. Adenois (Moq.) Mosyakin \& Clemants (incl. Dysphania sect. Roubieva (Moq.) Mosyakin \& Clemants). The new nomenclatural combination Dysphania atriplicifolia (Spreng.) G.Kadereit, Sukhor. \& Uotila (in Uotila et al., 2021: 542) has been properly validated, based on these phylogenetic findings.

When providing my open review of the manuscript by Uotila et al. in 2020, I recommended the authors to recognize the Cycloloma lineage at the sectional or at least subsectional level, considering its phylogenetic position and the morphological distinctiveness ${ }^{1}$.

1 "I think that a separate section or at least subsection should be recognized for the former Cycloloma (one of possible new combinations: Dysphania sect. Cycloloma (Moq.) AUTHORS or Dysphania sect. Adenois (Moq.) Mosyakin \& Clemants subsect. Cycloloma (Moq.) AUTHORS). Its unique morphological characters (well described in the manuscript) and phylogenetic position as probably sister to the rest of taxa of that group are sufficient reasons for that. Also, recognition of subsections in Dysphania sect. Dysphania can be considered as well" (from my review of the manuscript; also, my email message of 22 July 2020 to Pertti Uotila). 
However, they preferred to place Dysphania atriplicifolia in sect. Adenois, thus stretching considerably the diagnostic morphological characters of the section to accommodate that morphologically deviant species. They, however, admitted that "it [D. atriplicifolia $]$ has unique morphological characters within the genus, which might allow to recognize a subsection for it. However, there are several American species, three of them morphologically distinctive, that were not included in our analysis, and due to lack of this information, no further division of $D$. sect. Adenois was adopted" (Uotila et al., 2021: 542). In my opinion, morphological characters of the former Cycloloma are too distant and dramatically different from those peculiar to Dysphania sect. Adenois: for example, (1) the connate perianth segments with a horizontal, membranous, circular wing, a unique feature of Cycloloma; (2) lax, almost leafless inflorescences with remote flowers/fruits in the Cycloloma lineage versus usually compact and dense linear inflorescences, or sometimes axillary clusters, in most of members of sect. Adenois (sensu stricto), (3) fruits in Cycloloma are larger than those in all members of sect. Adenois; (4) the tumbleweed life form in Cycloloma is not similar to the general plant architecture in most of taxa of sect. Adenois. Several other arguments can be added as well.

Dysphania R.Br. sect. Cycloloma (Moq.) Mosyakin, comb. et stat. nov.

Basionym: Cycloloma Moq., Chenop. Monogr. Enum.: 17 (1840).

Type: Cycloloma platyphyllum (Michx.) Moq., Chenop. Monogr. Enum.: 18 (1840).

= Amoreuxia Moq., Mem. Soc. Hist. Nat. Monsp. (1826) [non vidi], nom. illeg. (later homonym, Art. 53.1 of the ICN: Turland et al., 2018), non Amoreuxia DC., Prodr. 2: 638. 1825 (Bixaceae, formerly Cochlospermaceae).

ECyclolepis Moq., Ann. Sci. Nat., Bot. sér. 2, 1: 203 (1834), nom. illeg. (later homonym, Art. 53.1 of the ICN: Turland et al., 2018), non Cyclolepis Gillies ex D.Don, Philos. Mag. Ann. Chem. 11: 392 (1832) (Asteraceae).

$\equiv$ Petermannia Rchb., Deut. Bot. Herb.-Buch: 153 (1841).

$\equiv$ Amorea Delile, Index Seminum [Montpellier] [issue of 1844]: 1 (1844).

The section contains only one species:

Dysphania atriplicifolia (Spreng.) G.Kadereit, Sukhor. \& Uotila, Taxon 70(3): 542 (2021). $\equiv$ Salsola atriplicifolia Spreng., Erster Nachtr. Bot. Gart. Halle: 35, adnot. 46 (1801). $\equiv$ Kochia atriplicifolia (Spreng.) Roth, Neue Beytr. Bot. 1: 177 (1802). 三 Cycloloma atriplicifolium (Spreng.) J.M.Coult., Mem. Torrey Bot. Club 5: 143 (1894). 三 Chenopodium atriplicifolium (Spreng.) A.Ludw. ex Graebn., Syn. Mitteleur. Fl. 5(1, Lief. 79 \& 80): 18 (1913).

= Salsola platyphylla Michx., Fl. Bor.-Amer. 1: 174 (1803). $\equiv$ Amoreuxia platyphylla (Michx.) Moq., Mem. Soc. Hist. Nat. Monsp. (1826) [non vidi]. Cyclolepis platyphylla (Michx.) Moq., Ann. Sci. Nat., Bot. sér. 2, 1: 203 (1834). E Cycloloma platyphyllum (Michx.) Moq., Chenop. Monogr. Enum.: 18 (1840). $\equiv$ Amorea platyphylla (Michx.) Delile, Index Seminum [Montpellier] [issue of 1844]: 1 (1844).

= Kochia dentata Willd., Hort. Berol. 1(3): tab. 28 (1804). $\equiv$ Salsola dentata (Willd.) Germann, Verz. Pfl. Bot. Gart. Kais. Univ. Dorpat [vol. of 1807]: 116 (1807).

= Chenopodium radiatum Schrad., Neues J. Bot. 3(3): 85 (1809).

Invalid names under which the species was occasionally cultivated or mentioned in the $19^{\text {th }}$ century:

$=$ Salsola latifolia hort. ex Poir. in Lam., Encycl. 7: 298 (1806), nom. inval. (pro syn., Art. 36.1(b) of the ICN: Turland et al., 2018).

= Salsola chenopodioides hort. ex Dum.Cours., Bot. Cult., ed. 2, 2: 463 (1811), nom. inval. (pro syn.).

= Salsola corymbosa hort. ex Moq. in DC., Prodr. 13(2): 60 (1849), nom. inval. (pro syn.).

= Salsola paniculata hort. ex Moq. in DC., Prodr. 13(2): 60 (1849), nom. inval. (pro syn.).

= Salsola stellata hort. ex Moq. in DC., Prodr. 13(2): 60 (1849), nom. inval. (pro syn.).

\section{On Australian groups of Dysphania sect. Dysphania (as outlined in Uotila et al., 2021)}

The phylogenetic analysis of Uotila et al. (2021) revealed three main clades in the Australian group that they recognized as Dysphania sect. Dysphania. It is noteworthy that these clades quite well correspond to the main morphology-based groups, usually recognized earlier as infrageneric taxa (sections) of either Chenopodium or Dysphania.

In particular, (1) the clade containing Dysphania carinata (R.Br.) Mosyakin \& Clemants, D. cristata (R.Br.) Mosyakin \& Clemants, D. melanocarpa (J.M.Black) Mosyakin \& Clemants, D. pumilio (R.Br.) Mosyakin \& Clemants, and D. truncata (Paul G.Wilson) Mosyakin \& Clemants corresponds to Dysphania sect. Orthospora (R.Br.) Mosyakin \& Clemants (三 Chenopodium sect. 
Orthosporum R.Br.: see Brown, 1810: 407; Scott, 1978b; Wilson, 1983, 1984; Mosyakin, Clemants, 2002, 2008, and references therein); (2) the clade of D. glandulosa Paul G.Wilson, D. glomulifera (Nees) Paul G.Wilson, D. littoralis R.Br., D. platycarpa Paul G.Wilson, and D. valida Paul G.Wilson corresponds to Dysphania sect. Dysphania (see Scott, 1978b; Mosyakin, Clemants, 2002; Clemants, Mosyakin, 2003); and (3) the clade of D. congestiflora S.J.Dillon \& A.S.Markey, D. plantaginella F.Muell., D. simulans F.Muell. \& Tate ex Tate, and D. sphaerosperma Paul G.Wilson contains taxa placed earlier in Dysphania sect. Tetrasepalae (Aellen) A.J.Scott ( $\equiv$ Chenopodium sect. Tetrasepala Aellen) (see Aellen, 1930b: 490; Scott, 1978b: 218; Mosyakin, Clemants, 2002; Dillon, Markey, 2017), while its subclade containing D. rhadinostachya (F.Muell.) A.J.Scott and D. kalpari Paul G.Wilson includes taxa earlier placed in Dysphania sect. Caudatae A.J.Scott (Scott, 1978b: 218). We propose to recognize these three well-outlined groups (clades) as subsections of Dysphania sect. Dysphania.

Dysphania sect. Dysphania subsect. Dysphania (autonym, Arts. 22.3 and 32.3 of the ICN: Turland et al., 2018).

Type: Dyspania littoralis R.Br., Prodr. Fl. Nov. Holland.: 407 (1810), the only species originally included in Dysphania by Brown (1810: 407).

Dysphania sect. Dysphania subsect. Orthospora (R.Br.) Mosyakin, comb. et stat. nov.

Basionym: Chenopodium L. sect. Orthosporum R.Br., Prodr. Fl. Nov. Holland.: 407 (1810). 三 Dysphania R.Br. sect. Orthospora (R.Br.) Mosyakin \& Clemants, Ukrayins'k. Bot. Zhurn. 59(4): 382 (2002).

Type: Chenopodium cristatum R.Br. (see Wilson, 1983: 169; Uotila et al., 2021: 543).

Dysphania sect. Dysphania subsect. Tetrasepalae (Aellen) Mosyakin, comb. et stat. nov.

Basionym: Chenopodium L. sect. Tetrasepala Aellen, Bot. Jahrb. Syst. 63: 490 (1930). $\equiv$ Dysphania R.Br. sect. Tetrasepalae (Aellen) A.J.Scott, Bot. Jahrb. Syst. 100(2): 218 (1978).

Type: Dysphania inflata (Aellen) A.J.Scott $\equiv$ D. rhadinostachya (F.Muell.) A.J.Scott subsp. inflata (Aellen) Paul G.Wilson (Scott, 1978b: 218; Uotila et al., 2021: 543).

= Dysphania R.Br. sect. Caudatae A.J.Scott, Bot. Jahrb. Syst. 100(2): 218 (1978).

Type: Dysphania plantaginella F.Muell. (see Scott, 1978b: 218).
These subsections (clades as outlined in Uotila et al., 2021) of Dysphania sect. Dysphania can be distinguished using the following key:

1. Perianth segments (tepals) normally 5 subsect. Orthospora

- Perianth segments (tepals) normally 4-1 ............. 2

2. Perianth segments (tepals) 4-3. Inflorescences dense, spike-like, leafless or almost leafless subsect. Tetrasepala

- Perianth segments (tepals) 2-1. Inflorescences interrupted, consisting mostly of axillary clusters .subsect. Dysphania

\section{On Chenopodium graveolens}

It was usually assumed that the name Chenopodium graveolens was first published by Willdenow (1809: 290; IPNI, 2021-onward: https://www.ipni.org/n/56134-2). However, that name is a later homonym (or an isonym?) of the earlier name Chenopodium graveolens that has been published earlier by Lagasca and Rodríguez (1802: 70) (see IPNI, 2021-onward: https://www.ipni. org/n/164958-1). In the Plants Of the World Online online database (POWO, 2021-onward, accessed 9 June and 5 July 2021) the name Chenopodium graveolens Lag. \& Rodr. (http://www.plantsoftheworldonline.org/ taxon/urn:Isid:ipni.org:names:164958-1) was listed on 9 June 2021 as a synonym of D. schraderiana (Schult.) Mosyakin \& Clemants, but later (accessed 5 July 2021) it was listed as a synonym of "Dysphania incisa (Poir.) ined.".

The name Chenopodium graveolens Willd. (http:// www.plantsoftheworldonline.org/taxon/urn:lsid:ipni. org:names:56134-2) was listed on 9 June and 5 July 2021 as a synonym of the same provisional combination, "Dysphania incisa (Poir.) ined.".

Digital images of and associated data on at least two original (or presumably original) specimens of Chenopodium graveolens Lag. \& Rodr. are available online from JSTOR Global Plants (https://plants.jstor. org/). Images of specimens of C. graveolens associated with Willdenow are available from both the Willdenow Herbarium at B (Virtual Herbarium Berolinense; http:// ww2.bgbm.org/herbarium/default.cfm) and JSTOR Global Plants.

The specimen MA214007 (image and data are available from: $\quad$ https://plants.jstor.org/stable/10.5555/al.ap. specimen.ma214007) contains five large branches plus small fragments in an envelope, and has the presumably 
original handwritten label ("Chenopodium graveolens | Lagasca et Rodríguez $\mid$ Anal. Scient. Natur. Vol. 9. pag. 70 | culta in hoc regio horto anno 1801. Floruit Septembri") and the curatorial label [printed and typewritten (name) text: "Ex antiquo herbario generali | Herbarium HorTI Botanici Matritensis | Chenopodium graveolens Lag. \& Rodr."]. It is listed in JSTOR Global Plants as "Type of Chenopodium graveolens Lag. et Rodr. ... (stored under name)". This specimen, which morphologically matches the original description by Lagasca and Rodríguez (1802: 70 ), is formally designated here as the lectotype of Chenopodium graveolens Lag. \& Rodr. (following the recommendations of McNeill, 2014).

Another presumably original specimen is available from the Herbario Universidad de Sevilla (SEV), SEV-H4090 (https://plants.jstor.org/stable/10.5555/al.ap. specimen.sev-h4090); it has a JSTOR Global Plants note "m. Rodríguez. Posible duplicado del pliego $\mathrm{n}^{\circ}$ HHUS 4089" and is listed as "Type of Chenopodium graveolens Lag. et Rodr. ... (stored under name)". The original status of that specimen is doubtful because no date of collection is available from the two labels on the sheet. However, the two plant fragments (branches) on that sheet clearly belong to the same species as Chenopodium graveolens sensu Willdenow (see comments on specimens from the Willdenow Herbarium below).

The specimen K000898413 (https://plants.jstor.org/ stable/10.5555/al.ap.specimen.k000898413) contains small plant fragments in an envelope; the sheet has also a typewritten excerpt from the protologue of Chenopodium graveolens Lag. \& Rodr. and the explanatory curatorial label "HERB. HORT. BOT. REG. KEW. | Chenopodium Botrys L. (C. graveolens | Lag. et Rodr.) | Specimen in Herb. Lagasca at Madrid, presumably | cultivated in the Botanic Garden there, Oct. 1822. | Specimen received on loan from the Jardin Botanico, Madrid, | 1949". It also has identification labels by Aellen ("Chenop. Botrys L.! | Det. Aellen 1961") and Uotila ("REVISIÓN PARA "FLORA IBERICA" | Chenopodium botrys L. | Det.-rev. Pertti Uotila XII 1984"), both indicating that the specimen belongs to C. botrys L. (now Dysphania botrys (L.) Mosyakin \& Clemants). Judging from the curatorial label and the date on it, that specimen does not belong to original material of $C$. graveolens Lag. \& Rodr. but in fact represents some plant cultivated under that name long after the actual date of publication of the name and description of $C$. graveolens Lag. \& Rodr. It should be noted that the name $C$. graveolens is not mentioned in the treatment of Chenopodium sensu lato in Flora Iberica (Uotila, 1990).
There are two specimens of Chenopodium graveolens in the Willdenow Herbarium at B. The specimen B-W05350-010 (https://plants.jstor.org/stable/10.5555/ al.ap.specimen.b\%20-w\%2005350\%20-01\%200) has Willdenow's inscription (top-right corner of the sheet) "Ch. graveolens. 1" and the annotation/identification label by Aellen: "Chenopodium graveolens Willd. | (Chenopodium incisum Poir. var. mexicanum Aellen).| det. P. Aellen | 10.03.1930". Another specimen, B-W05350-020 (https://plants.jstor.org/stable/10.5555/ al.ap.specimen.b $\% 20-\mathrm{w} \% 2005350 \% 20-02 \% 200)$, bears Willdenow's annotation (top-right corner of the sheet) "Ch. graveolens. 2".

Both these specimens from the Willdenow Herbarium belong to the same species as the specimen MA214007 (see above).

The specimen P00606423 (image and data available from $\quad$ https://plants.jstor.org/stable/10.5555/al.ap. specimen.p00606423) with the label "Chenopodium incisum | [illegible] | herb. Poiret. h. par. [hortus parisiensis]" seems to be the only original specimen of Chenopodium incisum Poir. directly associated with Poiret, and thus it is listed in JSTOR Global Plants as the "Holotype of Chenopodium incisum Poir.". It is conspecific with herbarium specimens of $C$. graveolens of Lagasca and Rodríguez and C. graveolens of Willdenow.

In my opinion, Art. 41.8(a) of the ICN (Turland et al., 2018) is directly applicable here. According to that article, "On or after 1 January 1953, in any of the following cases, a full and direct reference to a work other than that in which the basionym or replaced synonym was validly published is treated as an error to be corrected, not affecting the valid publication of a new combination, name at new rank, or replacement name: $(a)$ when the actual basionym or replaced synonym was validly published earlier than the name or later isonym cited as such, but in the cited publication, in which all conditions for valid publication of the name as cited are fulfilled, there is no reference, in association with that name, to the place of valid publication of the actual basionym or replaced synonym $<\ldots>$.

We may assume that the plant species cultivated in Berlin under the name Chenopodium graveolens was received under that name either directly from Madrid or through some other botanical garden, and thus Willdenow used the name actually provided by Lagasca and Rodríguez but for some reason did not mention that reference. Thus, Mosyakin and Clemants (2002: 383) provided the full and direct reference to the description of C. graveolens in the book by Willdenow (1809), a work 
other than that in which the actual basionym was validly published (which was in fact the article by Lagasca and Rodríguez of 1802), but that should be treated as an error to be corrected because the actual basionym (in our case, C. graveolens Lag. \& Rodr.) was validly published earlier than the name or later isonym cited as such (C. graveolens attributed to Willdenow) but in the cited publication (Willdenow, 1809) all conditions for valid publication of the name as cited were fulfilled, and there was no reference to the place of valid publication of the actual basionym (Lagasca, Rodríguez, 1802). Consequently, a new combination in Dysphania based on Chenopodium incisum (provisionally cited in POWO as "Dysphania incisa (Poir.) ined.") is not needed. It should be also noted that Zhang and Zhu (2016; see also Zhu, Sanderson, 2017), when making a new nomenclatural combination Neobotrydium graveolens (Lag. \& Rodr.) M.L.Zhang \& G.L.Chu, cited the name by Lagasca and Rodríguez as the basionym.

The corrected nomenclatural citation of Dysphania graveolens is provided below:

Dysphania graveolens (Lag. \& Rodr.) Mosyakin \& Clemants, Ukrayins'k. Bot. Zhurn. [Ukr. Bot. J.] 59(4): 383 (2002) (cited with the authorship "(Willd.) Mosyakin \& Clemants"). $\equiv$ Chenopodium graveolens Lag. \& Rodr., Anales Ci. Nat. 5: 70 (1802). $\equiv$ Teloxys graveolens (Lag. \& Rodr.) W.A.Weber, Phytologia 58: 478 (1985), with the authorship "(Willd.) W.A.Weber" (see Weber, 1985: 478). $\equiv$ Neobotrydium graveolens (Lag. \& Rodr.) M.L.Zhang \& G.L.Chu, Pl. Diversity 38: 327 (2016) (see also Zhu, Sanderson, 2017: 73).

= Chenopodium graveolens Willd., Enum. Pl. Berol. 1: 290 (1809) (isonym?).

= Chenopodium incisum Poir., Encycl., Suppl. 1: 392 (1810).

\section{Acknowledgments}

I am grateful to colleagues who provided their assistance and expertise during the preparation of the present nomenclatural note, or provided PDF copies of some publications, especially to Rafaël H.A. Govaerts (Royal Botanical Gardens, Kew, U.K.), Pertti Uotila (Finnish Museum of Natural History, Botany Unit, University of Helsinki, Helsinki, Finland), and Filip Verloove (Meise Botanic Garden, Meise, Belgium). Ganna V. Boiko and Vera P. Hayova (M.G. Kholodny Institute of Botany, National Academy of Sciences of Ukraine,
Kyiv, Ukraine) guided the present submission through the editorial process and made several improvements in the text, and their assistance is gratefully acknowledged. Useful comments of two anonymous reviewers were gratefully accepted in the final version and are greatly appreciated.

\section{References}

Aellen P. 1930a. Die systematische Stellung und Gliederung der R. Brownischen Gattung Dysphania. Botanische Jahrbücher für Systematik, Pflanzengeschichte und Pflanzengeographie, 63: 482-490.

Aellen P. 1930b. Eine neue Sektion der Gattung Chenopodium (Sect. Tetrasepala). Botanische Jahrbücher für Systematik, Pflanzengeschichte und Pflanzengeographie, 63: 490-492.

Britton N.L., Coulter J.M., Rusby H.H., Kellerman W.A., Coville F.V., Underwood L.M., Ward L.F. 1894. List of Pteridophyta and Spermatophyta growing without cultivation in Northeastern North America. Memoirs of the Torrey Botanical Club, 5: 5-377.

Brown R. 1810. Prodromus florae Novae Hollandiae et Insulae Van-Diemen. Londini [London]: Typis Richardi Taylor \&socii, viii+ pp. 145-590. https://doi.org/10.5962/ $\underline{\text { bhl.title.52309 }}$

Cabrera J.F., Jacobs S.W.L., Kadereit G. 2009. Phylogeny of the Australian Camphorosmeae (Chenopodiaceae) and the taxonomic significance of the fruiting perianth. International Journal of Plant Sciences, 170(4): 505-521. https://doi.org/10.1086/597267

Cabrera J., Jacobs S.W.L., Kadereit G. 2011. Biogeography of Camphorosmeae (Chenopodiaceae): tracking the Tertiary history of Australian aridification. Telopea, 13(1-2): 313326. https://doi.org/10.7751/telopea20116023

Clemants S.E., Mosyakin S.L. 2003. Dysphania. In: Flora of North America Editorial Committee (eds.). Flora of North America North of Mexico, vol. 4. New York; Oxford: Oxford University Press, pp. 275-300.

Delile [Raffeneau-Delile] A. 1844. Index Seminum Horti Regii Botanici Monspeliensis, anni 1844. Monspelii [Montpellier], 4 pp.

Dillon S.J., Markey A.S. 2017. Dysphania congestiflora (Chenopodiaceae), a new species from Western Australia. Nuytsia, 27: 133-138. Available at: https://florabase.dpaw. wa.gov.au/nuytsia/article/793

Fuentes-Bazan S., Mansion G., Borsch T. 2012a. Towards a species level tree of the globally diverse genus Chenopodium (Chenopodiaceae). Molecular Phylogenetics and Evolution, 62: 359-374. https://doi. org/10.1016/j.ympev.2011.10.006

Fuentes-Bazan S., Uotila P., Borsch T. 2012b. A novel phylogeny-based generic classification for Chenopodium sensu lato, and a tribal rearrangement of Chenopodioideae (Chenopodiaceae). Willdenowia, 42(1): 5-24. https://doi. org/10.3372/wi.42.42101 
Hernández-Ledesma P., Berendsohn W.G., Borsch T., von Mering S., Akhani H., Arias S., Castañeda-Noa I., Eggli U., Eriksson R., Flores-Olvera H., FuentesBazán S., Kadereit G., Klak C., Korotkova N., Nyffeler R., Ocampo G., Ochoterena H., Oxelman B., Rabeler R.K., Sanchez A., Schlumpberger B.O., Uotila P. 2015. A taxonomic backbone for the global synthesis of species diversity in the angiosperm order Caryophyllales. Willdenowia, 45(3): 281-383. https://doi.org/10.3372/ wi.45.45301

IPNI. 2021-onward. International Plant Names Index. The Royal Botanic Gardens, Kew, Harvard University Herbaria \& Libraries and Australian National Botanic Gardens. Available at: https://www.ipni.org/ (Accessed 9 June 2021 and 5 July 2021).

Kadereit G., Freitag H. 2011. Molecular phylogeny of Camphorosmeae (Camphorosmoideae, Chenopodiaceae): Implications for biogeography, evolution of $\mathrm{C}_{4}$ photosynthesis and taxonomy. Taxon, 60(1): 51-78. https://doi.org/10.1002/tax.601006

Kühn U. (with additions by Bittrich V., Carolin R., Freitag H., Hedge I.C., Uotila P., Wilson P.G.) 1993. Chenopodiaceae. In: Kubitzki K., Rohwer J.G., Bittrich V. (eds.). The families and genera of vascular plants, vol. 2. Berlin; Heidelberg; New York: Springer; pp. 253-281.

Lagasca M., Rodriguez J. 1802. Descripciones de algunas plantas nuevas que han florecido en el Real establecimiento botanico en el año 1801. Anales de Ciencias Naturales (Madrid), 5: 65-76. Available at: https://www. biodiversitylibrary.org/bibliography/14767

McNeill J. 2014. Holotype specimens and type citations: general issues. Taxon, 63(5): 1112-1113. https://doi. org/10.12705/635.7

Moquin-Tandon A. 1834. Descriptions de plusieurs nouveaux genres de Chénopodées (Nova Chenopodearum genera). Annales des Sciences Naturelles (Paris), Sér. 2, 1: 203211, 289-294 + pl. 9, 10.

Moquin-Tandon A. 1840. Chenopodearum monographica enumeratio. Parisiis [Paris]: P.-J. Loss, xi + 182 pp. https:// doi.org/10.5962/bhl.title.15484

Moquin-Tandon A. 1849. Ordo Salsolaceae. In: Candolle A.P. (ed.), Prodromus systematis naturalis regni vegetabilis, vol. 13(2). Parisiis [Paris]: SumptibusVictoris Masson, pp. 41-219. https://doi.org/10.5962/bhl.title.286

Morales-Briones D.F., Kadereit G., Tefarikis D.T., Moore M.J., Smith S.A., Brockington S.F., Timoneda A., Yim W.C., Cushman J.C., Yang Y. 2021 (online before print: 2020). Disentangling sources of gene tree discordance in phylogenomic datasets: Testing ancient hybridizations in Amaranthaceae s.1. Systematic Biology, 70(2): 219-235. https://doi.org/10.1093/sysbio/syaa066

Mosyakin S.L. 2003. Cycloloma. In: Flora of North America Editorial Committee (eds.). Flora of North America North of Mexico, vol. 4. New York; Oxford: Oxford University Press, pp. 264-265.

Mosyakin S.L., Clemants S.E. 2002. New nomenclatural combinations in Dysphania R.Br. (Chenopodiaceae): Taxa occurring in North America. Ukrainian Botanical Journal,
59(4): 380-385. Available at: https://www.researchgate. net/publication/272417640

Mosyakin S.L., Clemants S.E. 2008. Further transfers of glandular-pubescent species from Chenopodium subgen. Ambrosia to Dysphania (Chenopodiaceae). Journal of the Botanical Research Institute of Texas, 2(1): 425-431. Available at: https://biostor.org/reference/157645 and https://www.biodiversitylibrary.org/part/161523

Mosyakin S.L., Iamonico D. 2017. Nomenclatural changes in Chenopodium (incl. Rhagodia) (Chenopodiaceae), with considerations on relationships of some Australian taxa and their possible Eurasian relatives. Nuytsia, 28: 255-271. Available at: https://florabase.dpaw.wa.gov.au/ science/nuytsia/843.pdf

POWO. 2021-onward. Plants of the World Online. Facilitated by the Royal Botanic Gardens, Kew. Available at: http:// www.plantsoftheworldonline.org/ (Accessed 9 June 2021 and 5 July 2021).

Reichenbach H.G.L. 1841. Das Herbarienbuch: Erklärung des natürlichen Pflanzensystems, systematische Aufzählung, Synonymik und Register der bis jetzt bekannten Pflanzengattungen... (Der deutsche Botaniker, Bd. 1). Dresden; Leipzig: In der Arnoldischen Buchhandlung, xcv + 240 pp. https://doi.org/10.5962/bhl.title.7694

Scott A.J. 1978a. Rhagodiinae: a new subtribe in the Chenopodiaceae. Feddes Repertorium 89(1): 1-11. https:// doi.org/10.1002/fedr.19780890102

Scott A.J. 1978b. A review of the classification of Chenopodium L. and related genera (Chenopodiaceae). Botanische Jahrbücher für Systematik, Pflanzengeschichte und Pflanzengeographie, 100(2): 205-220.

Scott A.J. 1978c. A revision of the Camphorosmioideae (Chenopodiaceae). Feddes Repertorium 89(2-3): 101119. https://doi.org/10.1002/fedr.19780890202

Simón L.E. 1996. Notas sobre Chenopodium L. subgen. Ambrosia A.J.Scott (Chenopodiaceae). 1. Taxonomía. 2. Fitogeografía: Áreas disyuntas. Anales del Jardin Botánico de Madrid, 54: 137-148.

Simón L.E. 1997. Variations des charactères foliares chez Chenopodium subg. Ambrosia sect. Adenois (Chenopodiaceae) en Amérique du Sud: Valeur taxonomique \& évolutive. Adansonia, sér. 3, 19(2): 293-320.

Sprengel K.[P.J.]. 1801. Erster Nachtrag zu der Beschreibung des botanischen Gartens der Universität zu Halle. Halle: Karl August Kümmel, viii + [9-] 44 pp.

Standley P.C. 1916. Chenopodiaceae. In: North American Flora, vol. 21(1). New York: The New York Botanical Garden, 93 pp. Available at: https:/www. biodiversitylibrary.org/item/15434

Turland N.J., Wiersema J.H., Barrie F.R., Greuter W., Hawksworth D.L., Herendeen P.S., Knapp S., Kusber W.-H., Li D.-Z., Marhold K., May T.W., McNeill J., Monro A.M., Prado J., Price M.J., Smith G.F. 2018. International Code of Nomenclature for algae, fungi, and plants (Shenzhen Code) adopted by the Nineteenth International Botanical Congress, Shenzhen, China, July 2017 [Regnum Vegetabile, vol. 159]. Glashütten: Koeltz 
Botanical Books, xxxviii + 254 pp. https://doi.org/10.1186/ s43008-019-0019-1

Uotila P. 1990. Chenopodium. In: Castroviejo S. (ed.). Flora Iberica, vol 2. Madrid: Real Jardín Botánico - CSIC, pp. 484-500.

Uotila P., Sukhorukov A.P., Bobon N., McDonald J., Krinitsina A.A., Kadereit G. 2021. Phylogeny, biogeography and systematics of Dysphanieae (Amaranthaceae). Taxon, 70(3): 526-551. https://doi.org/10.1002/tax.12458

Weber W.A. 1985. The genus Teloxys (Chenopodiaceae). Phytologia, 58(7): 477-478. Available at: https://www. biodiversitylibrary.org/part/176202

Willdenow C.L. 1809. Enumeratio Plantarum Horti Regii Botanici Berolinensis: continens descriptiones omnium vegetabilium in horto dicto cultorum. Berolini [Berlin]: In Taberna libraria Scholae Realis, vi + 1099 pp.
Wilson P.G. 1983. A taxonomic revision of the tribe Chenopodieae (Chenopodiaceae) in Australia. Nuytsia, 4(2): 135-262. Available at: https://www. biodiversitylibrary.org/page/53204842

Wilson P.G. 1984. Chenopodiaceae. In: George A.S. (ed.). Flora of Australia, vol. 4. Canberra: Australian Government Publishing Service, pp. 81-317.

Zhang M.L., Zhu G.L. 2016. Resurrection of the genus Botrydium Spach (Chenopodiaceae), with a description of four new species from China, Peru and Burundi. Plant Diversity, 38(6): 322-329. https://doi.org/10.1016/j. pld.2016.10.005

Zhu G.L., Sanderson S.C. 2017. Genera and a new evolutionary system of World Chenopodiaceae. Beijing: Science Press, 361 pp.

Recommended for publication by F. Verloove

Мосякін С.Л. 2021. Номенклатурні та таксономічні коментарі щодо деяких представників роду Dysphania (Chenopodiaceae s. str. / Amaranthaceae s. 1.). Украӥнський ботанічний журнал, 78(4): 266-273 [In English].

Інститут ботаніки ім. М.Г. Холодного НАН України, вул. Терещенківська 2, Київ 01601, Україна: С.Л. Мосякін

Реферат. Представлені коментарі щодо системи роду Dysphania у його уточненому обсязі, зміненому відповідно до результатів недавніх детальних молекулярно-філогенетичних досліджень (Uotila et al., 2021). Запропоновані зміни та доповнення до схеми 3 п'яти секцій, представленої Uotila et al. (2021). Зокрема, морфологічно чітко окреслена філогенетична лінія, що наразі містить єдиний вид Dysphania atriplicifolia (раніше загальновизнаний як єдиний вид роду Cycloloma, C. atriplicifolium), визнана як окрема секція - Dysphania sect. Cycloloma (Moq.) Mosyakin, comb. et stat. nov. Подана детальна синоніміка секції та їі єдиного виду. Філогенетичні лінії, виявлені в австралійській кладі Dysphania sect. Dysphania, досить добре окреслені морфологічно; раніше вони здебільшого визнавалися як секції Chenopodium (sensu lato) або Dysphania. Ці групи визнані тут як підсекції в межах Dysphania sect. Dysphania: (1) subsect. Orthospora (R.Br.) Mosyakin, comb. et stat. nov.; (2) subsect. Dysphania; та (3) subsect. Tetrasepalae (Aellen) Mosyakin, comb. et stat. nov. Обговорена проблема номенклатури Dysphania graveolens (三 Chenopodium graveolens). Підтверджено, що назва Chenopodium graveolens була вперше валідно опублікована не Вільденовом (Willdenow) у 1809 р., а Лагаскою (Lagasca) та Родрігесом (Rodríguez) у 1802 р. Оригінальні зразки, асоційовані з цією назвою в обох публікаціях, з таксономічної точки зору належать до виду, який зараз відомий як Dysphania graveolens (= Chenopodium incisum Poir.). На мою думку, тут слід застосувати Ст. 41.8(a) Міжнародного кодексу номенклатури водоростей, грибів та рослин (Шеньчженьський Кодекс). Відповідно, назва D. graveolens має цитуватися з уточненим авторством "(Lag. \& Rodr.) Mosyakin \& Clemants", а потенційна нова комбінація у роді Dysphania на основі базіоніму Chenopodium incisum (провізорно наведена у базі даних POWO як "Dysphania incisa (Poir.) ined.") не потрібна.

Ключові слова: Chenopodium, Cycloloma, Dysphania, номенклатура, систематика 